\title{
Indian English as the Tongue of Indian Christians
}

\author{
Dr. Veena R. Ilame
}

Assistant Professor, Department of English, A. G. College, Nagpur-440013, Maharashtra, India

\begin{abstract}
This research paper aims to prove that English was introduced in India for Indian Christians, and it is a Christian tongue, which is used as a spiritual language for the spiritual growth in many Indian churches. On the other hand, Indian Christian claim, it as their mother tongue rather than Anglo-Indians who boast that it is their mother tongue even though most of the Anglo-Indians do not know how to speak proper English. The Blueprint of English Education was framed by Evangelical Anglicans who wanted to impart Western Education through the medium of English in India for the sake of social reformation through proselytization of barbarian Hindus. In the present scenario, Indian Christians spreading Indian languages and preventing convertees from preaching in English still Indian Christians are three per cent of Indian Population. English and English Education system both were introduced in India for Indian Christians who are the natives of India professing any form of the Christian faith who are progenies of the convertees and such converts. In the present scenario, there are several Pakistani, Bangladeshi, Srilankan, Burmese, and Indian Christians who have made English as their Spiritual and first acquired Language and they use it as their mother tongue and spiritual language, and thus it has been their tongue since the period of the British Raj.
\end{abstract}

Keywords-English, India, Christians, tongue, Western, Education.

\section{INTRODUCTION}

Indian English is the language spoken by Indian and it is the Indian variety of the English language, which is internationally recognized. It is one of the Indian languages because Indians use it. It is the mother tongue of the Anglo-Indians who are natives of India. However, East India Company introduced it for the Indian Christians over the British Raj in the Indian subcontinent. Anglican Evangelicals were angels of poor and eager to spread the gospel through English to the Hindus in India. They wished that the gospel should be preached to Indians through English. They wanted to impart instruction through the medium of English, on the other hand, several Indian masters and pastors in India are misguiding Indian converts and compel them to speak the local tongues and worship God in the vernaculars.

\section{CHRISTIAN COMMUNITY}

There are three streams of the Indian Christina community in Pakistan, Bangladesh, Burma, India and Srilanka: Indian Christians, and Anglo-Indians, Europeans who regard themselves, brethren and sisters. On the other hand, there are many Christians who are from the United States of America, Germany, Norway, Switzerland, France, Italy and so many other countries who harmoniously have mingled with Indian Christians and they have become part of Indian Christian Community.

Firstly, it is essential to know who an Indian Christian is. An Indian Christian is a person who is a native of India and a descent of a person who was converted to the Christian faith or such convert following any form of the Christian religion. All Hindu converts and the person whose ancestors were converted to the Christian faith are Indian Christians in the sight of the Indian law since the period of the British Raj. According to the Government of India Act, 1935," an Indian Christian means a person who professes any form of the Christian religion and is not a European or an Anglo-Indian"( Ch2: 217). The term "Indian Christians "includes the Christian descendants of natives of India converted to Christianity as well as such converts. On the other hand, An Anglo-Indian signifies a person "whose father or any of whose other male progenitors in the male line is or was of European descent but who is a native of India (Govt. India Act, 1935: 217). Besides it is essential to know that "a European means a person whose father or any of whom other male progenitors in the male line are or were of European descent and who is not a native of India (Govt. of India Act: 217). It is possible to believe that the people of these three streams of Indian Community have fellowship with each other. 


\section{GENESIS OF INDIAN ENGLISH}

It is also crucial to know what Indian English is. Indian English is the form of British English used by Indians. Although English is the mother tongue of Anglo-Indians, Indian Christians use it as their first acquired language.

Thirdly, I desire to take all readers to the Blue Print of the English Education in India so that you may understand the seriousness of the problem of the research paper. $\mathrm{N}$. Krishnaswamy and Lalitha Krishnaswamy rightly remarks:

The first blueprint on English education in India was prepared in 1792 by Charles Grant, a director of the East India Company. Charles Grant, described as the Christian Director of the EIC, was also a member of the Evangelical party known as the Clapham Class or Sect, which had on its roll such men as Zachary Macaulay, the father of Lord Macaulay, and William Wilberforce, a champion of the poor. They were men of religious zeal, keen on spreading Christianity through English, known as the "Christian tongue in the early stages of its introduction in India. For an Englishman of that Period, acceptance of the Christian faith meant not just the acceptance of a religion with a set of beliefs and rituals, but the cultivation of the mind with the knowledge of the cultural, economic, and social achievements of the Community. (11)

English was a Christian tongue introduced for the evangelization of Indians through the medium of English.

On his advent to India in 1767, Charles Grant inscribed the treatise "Observations on the State of the Society among the Asiatic Subjects of Great Britain, particularly concerning Morals and the Means of Improving it" in 1792 , and in which he suggested that it was a policy to produce a change in the Indian society (Moral, social, and mental) through the English language, Western Education and Christianity. It was the evangelist - Charles Grantwho had equated God with the protector of British commerce, and the missionary in him had equated truth with the English language, Western Education, and Christianity (Krishnamurthy \& Et. El 11, 12). Charles Grant lived in India from 1767 to 1790 with a break during 1771-73 who suggested:

The true [real] curse of darkness is the introduction of light. The Hindus err because they are ignorant and their errors have never fairly [somewhat] been laid before them. The communication of light and knowledge to them would prove the best remedy for their children, and this remedy is proposed from a full conviction that if judiciously and patiently applied, it would have great[tremendous] and happy effects upon them, effects honourable and advantageous for us. (qtd. in Syed, 11).
It is possible to believe that the Hindus were possibly in darkness during those days, and they needed to be enlightened. Charles Grant recommended that western Education should be imparted to Indians through English medium and English should be adopted as an Official language because Persian was the language of the court of Law and Government offices. Grant opined that the Christian faith through the medium of English "is the only remedy for all the evils in Hindu society and liberation of the Hindu mind. Charles Grant suggests:

Wherever this knowledge would be received idolatry, with all the rabble of its impure deities, its monsters of wood and stone, its false principles and corrupt practices, its delusive hopes and vain, vain fears, its ridiculous ceremonies and degrading superstitions, its lying legends and fraudulent impositions would fall. The reasonable service to the only and infinitely perfect God would be established: love to Him, peace, and goodwill towards men would be felt as obligatory principles. (qtd in Syed 113-14)

The English language and Western systems of Education were only the means for a cultural and religious conquest of the Hindus. "The master and the pastor were to be used as tools to bind the British Empire with the Christian religion. Grant compelled the British Government to introduce the English language in India. It was meant for the Christian convertees from Hinduism who may be called Indian Christians. In favour of English education, Charles Grant, Zachary Macaulay, William Wilberforce, and others argued relentlessly. William Wilberforce moved the following resolution in 1793 before the British Parliament:

That it is the peculiar and bounden duty of the British legislature to promote by all just and prudent means the interest and happiness of the inhabitants of the British domains in India; and that for these ends such measures ought to be adopted as may gradually tend to their advances in useful knowledge and their religious and moral improvements...The Court of Directors of the Company shall be empowered and committed to nominate and send out from time to time a sufficient number of skilled and suitable persons who shall attain the aforesaid object by serving as schoolmasters, missionaries, or otherwise. (qtd. in Richter 149-50).

William Wilberforce, an Angelical Evangelical, had a missionary zeal for the uplift of the poor in India and he was also concerned about the Hindus groping into darkness and he wished to enlighten the benighted people of India through Western Education and the English language.

According to J. A. Richter, it was the Court of the Company, which was empowered and committed to nominate and send out from time to time a sufficient number of skilled and suitable persons who had to attain the previously mentioned object "by serving as 
Jul-Aug 2020 /Available online: https://ijels.com/

schoolmasters, missionaries, or otherwise (149-50). What N. Krishnamurthy and Lalitha Krishnamurthy say is pertinent:

Wilberforce's resolution was too explicit in its motives and too clumsy worded to be accepted in toto, The House rejected the operative part of the resolution because the British did not want cultural confrontation with Indians. The resolution also went against the policy of Warren Hastings who, as Governor during 1772-85, had been keen on respecting Indian traditions. His main aims had been consolidation and conciliation. He founded the Calcutta Madrassa in 1781 and the Benares Sanskrit College in 1791, to encourage Oriental learning, both Muslims and Hindu. (14)

It is this that the Dalit had no right of education and there were no educational institutions for the depressed classes in India. As they were part of the Hindu society, they were unhallowed to enter the Maktabs and Madrasas, while the scriptural injunctions prevented them from learning Sanskrit and they were unable to educate themselves since schools were conducted in Hindu temples or at the Priestly race's dwelling places or pathshalas where their entry was banned due to the fright of pollution. The door of education was closed for females and down=trodden personas. When the English Education Act was introduced in 1835, they first attained that right and therefore English is the mother of Dalits in India. There was a tussle between Orientalists and Occidentalism. S.N. Mukherjee in his "A History of Education in India" (1951) aptly remarks:

The founding of these educational institutions marks the beginning of what is known as the Oriental School of Education Policy in the Government of British India. Even in the Company, one section though that overt support of the missionary enterprise in India would be counterproductive and it was better to follow the policy of non-interference. Based on political considerations, the Court of Directors accepted the views of the Orientalists. The expenditure incurred by the running of the Calcutta Madrassa and the Benares Sanskrit College was to be borne by the Government of the Company was that 'the Hindus had as good a system of faith and morals as most people and that it would be madness to attempt their conversion or to give any more learning or any other description of learning that what they already possessed' (Sharp: 17). Besides, there was also a lurking fear about the dangers of educating the subjects in the colonies. A prominent member of the Parliament said:' we have lost our colonies in America by imparting our education there; we need not do so in India too'. (32)

Charles Grant and his friends thought it was the bounden duty of the East India Company and the British Raj in India to educate Indians. Indian Education was an instrument for the uplift of the poor and needy. Another view was that Indians should learn English for reading the King James Version, which was regarded as the true word of God. Anglican Evangelical Faith is solely responsible for English Education in India. Many missionaries went to Dalits, converted them to Christianity, and opened the door of education for them.

\section{THE STRATEGIES OF THE MISSIONARIES}

Christian missionaries had their strategies as "the operative part of the 1793 Resolution, and they sought to send out to India several masters, pastors, ministers and evangelists for spreading the Christian knowledge amidst Indians. They criticised the company and the Government policies. What Nasrallah and Naik's remarks are pertinent:

Between 1792 and 1813, the East India Company did not ordinarily issue a permit to any missionary to work within its territories, expelled several missionaries as soon as they became active, tied to convert people, put every obstacle possible in the way of the missionaries, and did not give any assistance even to mission schools. (69)

Some people in the company was not in favour of evangelical work, and they wanted only the missionaries closely associated with their Anglican and Presbyterian faith. Besides, the company was reluctant to do so since there was a danger of uproar in India. Sometimes the East India Company demonstrated a considerable religious fervour. According to Dr Babasaheb Ambedkar, in 1614, the Captain of the Company's ship had brought a young Indian to London. The company educated him at its own expense' to be an instrument in converting some of his nations'. His baptism was performed at Poplar. The Lord Mayor of London and the Directors of the Company attended the baptism. Kind James I chose for him the name Peter and the priest who baptised him presented him to the Audience as "the first fruit of India" (461). The Church of England had already appointed several chaplains in India to minster their staff working in a variety of spheres and they conducted church services regularly. That was the beginning of English as a spiritual language of the Indian Christians in India. Anglicans advocated western education through the medium of English in India criticising Orientalists, the company and the Government, and Charles Grant and his friends were in the favour of the English language.

The fact seems to indicate that the year 1813 saw flocks of Christina missionaries entering India "intending to educate Indians and convert them to anew language, a new culture and a new language", The new faith was Evangelical Anglican, the new language, English and the new culture was Western Christian Culture practised in the United 
Jul-Aug 2020 /Available online: https://ijels.com/

Kingdom, and they were encouraged by the officials of the Company and the Government(Krishnamurthy 18).

English was a passport for the uplift of poor Indians as well as elites in India. Several tribal and Dalits uplifted themselves by adopting the faith of Jesus Chris.

\section{PRAISEWORTHY ENDEAVOURS OF LORD MACAULAY}

Lord Macaulay arrived in India in June 1834. He was the first member of the General's Executive Council and was appointed President of the General Committee of Public Instruction. Over William Bentinck's accession to the Governor Generalship in 1828 altered the situation considerably. Bentinck, Macaulay, and Charles grant $\mathrm{Jr}$ formed a suitable team. Lord Thomas Babington Macaulay rendered the English language to India permanently. He presented his minutes and advocated the Western education through the medium of English in 1835; when the English Education Act was passed in 1835, first the Dalit in Indian attained a right to take education. Macaulay considered that education was also an instrument of proselytization. When his minutes were accepted in 1835 , he pertinently pointed out:

No Hindu, who has received an English education, ever remains sincerely attached to his religion. Some continue to profess it as a matter of policy, but many profess themselves pure Deists and some embrace Christianity. It is my firm belief that if our plans of education are followed up, there will not be a single idolater among the respectable classes in Bengal thirty years hence. And this will be effected without any effort to proselytize; without the smallest interference in their religious liberty; merely by the operation of knowledge and reflection. (qtd. in Mayhew 15-16)

It shows that Macaulay also opines that English was introduced for Indian Christians.

\section{CONCLUSION}

In the present scenario in India, the Brahmins are flexible and they embraced westernization and made eye-catching progress. Many tribal adopted Christianity and commenced to exploit English as their mother tongue in India. Several pastors misguide and misdirect Indian Christians and ask them to speak Hindi due to their false pride, and many new converts are compelled to employ Hindi instead of English. Several Indian, Pakistani and Bangladeshi Christians have remained poor and needy as they have not yet realised the significance of the English language, for instance, in Pakistan Churah Christians are appointed by Pakistan. It can be argued that English is a Christian tongue and it is an Indian language which should be spoken by Indian Christians for their uplift and progress. It is conducive to shun the linguistic distinction and hatred. For unity, witnesses and service it is necessary to have one language and one culture amidst of all Indian Christians.

\section{REFERENCES}

[1] Ambedkar, D. B. (1989). Writings and Speeches (Vol. 5). (V. Moon, Ed.) Bombay, Maharashtra, India: Government of Maharashtra.

[2] Government of India Act, 1935, British Parliament, London, Schedule one.

[3] Chatterji, R. (1983). Impact of Raja Rammohan Roy on Education in India. New Delhi: S. Chand and Co.

[4] J.P.Naik, S. N. (1962). A Student's History of Education in India(1810-1961). Delhi: Macmillan.

[5] Krishnamurthy, N. K. (2013). The Story of English in India. New Delhi: Foundation Books.

[6] Ling, T. (1968). A History of Religion: East and West. London: Macmillan.

[7] Mayhew, A. (1928). The Education of India. London: Faber and Faber.

[8] Mukherji, S. N. (1951). A History of Education in India. Baroda: Baroda Publication.

[9] Richter, J. (1908). A History of Mission in India. Trans. S. W. Moore. Edinburgh and London.

[10] Sharp, W. H. (n.d.). Slection from Educational Records I.

[11] Syed, M. (1895). A History of English Eduaction in India. Delhi: Idarah-i, Adbiyat_I. 